Document downloaded from:

http://hdl.handle.net/10251/62574

This paper must be cited as:

Martí Selva, ML.; Puertas Medina, RM.; LEANDRO GARCIA (2014). Importance of the logistics performance index in international trade. Applied Economics. 1-11. doi:10.1080/00036846.2014.916394.

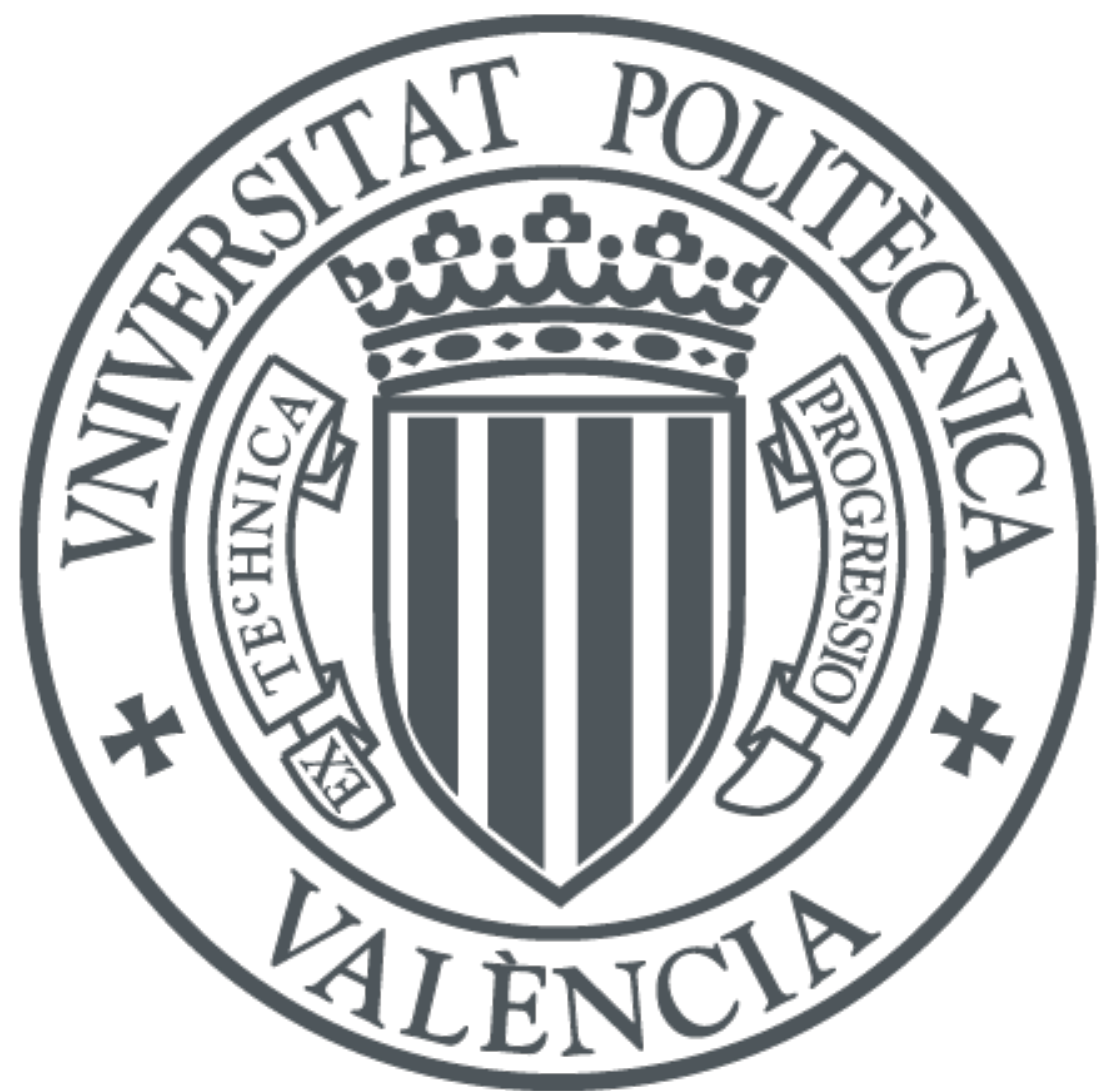

The final publication is available at

http://dx.doi.org/10.1080/00036846.2014.916394

Copyright Taylor \& Francis (Routledge): SSH Titles

Additional Information

This is an author's accepted manuscript of an article published in:

"Applied Economics"; Volume 46, Issue 24, 2014; copyright Taylor \& Francis; available online at: http://dx.doi.org/10.1080/00036846.2014.916394 


\title{
IMPORTANCE OF THE LOGISTICS PERFORMANCE INDEX IN INTERNATIONAL TRADE
}

\author{
L. Martí ${ }^{a^{*}}$, R. Puertas ${ }^{\mathrm{b}}$ and L. García ${ }^{\mathrm{c}}$ \\ ${ }^{a}$ Grupo de Economía Internacional. Universidad Politécnica de Valencia.Camino de Vera s/n 46022 \\ Valencia \\ ${ }^{b}$ Grupo de Economía Internacional. Universidad Politécnica de Valencia, Camino de Vera s/n 46022 \\ Valencia \\ ${ }^{c}$ Instituto de Economía Internacional. Universidad de Valencia. Avd. Tarongers s/n 46022 Valencia
}

*Corresponding author. E-mail: mlmarti@esp.upv.es

\begin{abstract}
Logistics and transport are becoming increasingly important in international trade relations. Logistic Performance Index (LPI) analyses the differences between countries, providing a general picture of customs procedures, logistics costs and the quality of the infrastructure necessary for overland and maritime transport. The aim of this article is to analyse the impact that each of the components that make up the LPI has on emerging countries' trade, employing a gravity model. Furthermore, the study also aims to detect possible advances in logistics in these countries, which are grouped into five regions (Africa, South America, Far East, Middle East and Eastern Europe) by comparing the first LPI data published in 2007 with the most recent data, released in 2012. The results obtained reveal that improvements in any of the components of the index cause the country to increase its volume of trade. Specifically, LPI components are becoming increasingly important for the countries in Africa, South America and Eastern Europe.
\end{abstract}

Keywords: LPI components, logistics, gravity model

JEL Code: C5, F1, H54 


\section{Introduction}

Globalization and increased competitiveness turned logistics into one of the key elements of trade. Efficient logistics services facilitate the mobility of products, ensuring their safety and speed as well as reduction in cost when trading them among countries. De Souza et al. (2007) define logistics as part of the value chain which plans, implements and controls the efficient flow of goods, services and information from source to consumer. Ultimately, the importance of logistics lies in the ability to efficiently solve transportation, storage and packaging issues, increasing the competitiveness of businesses and the country in general.

As Mustra (2011) suggests, logistics is one of the most important elements of national competitiveness. The quality logistic services and the infrastructures have a strong effect over the facilitation of transport of goods between countries. In contrast, inefficient logistics results in higher costs in terms of time and money, adversely affecting countries and companies, or reducing turnover as demonstrated by Hausman et al. (2005). The OECD (2005) estimates that logistics costs range between $2 \%$ and $15 \%$ of total turnover. So, logistics is playing an important role in international competition.

In this context, the literature has focused on the so-called trade facilitation measures, which represent an attempt to overcome the set of key non-tariff barriers difficulting the ongoing trade between countries. In emerging countries those are not sufficiently developed, causing an increase in trading costs and hindering the efficient movement of goods across borders, due to weak infrastructure, complex customs procedures and excessive bureaucracy between government agencies.

An assessment of trade facilitation measures can be approached through the Logistics Performance Index (LPI) published by the World Bank in 2007, 2010 and 2012 for a total of 150 countries. This index allows the differences between countries to 
be analysed, providing an overview of customs procedures, logistics costs and the quality of the infrastructure necessary for land and sea transport.

The aim of this study is to analyse the impact LPI and each of its components has on the trade of emerging countries with a maritime boundary using a gravity model. Furthermore, the study also aims to detect possible advances in logistics in these countries, which are grouped into five regions (Africa, South America, Far East, Middle East and Eastern Europe) by comparing the first LPI data published in 2007 to the most recent data, released in 2012.

The article is structured as follows. Section II reviews the literature that addresses logistics and transport as determinants of international trade. Section III describes both the make-up of the LPI and also how it scores each country. Section IV explains the gravity model methodology applied in the empirical part of the article. Section V details the sample and the variables used. Section VI presents the results of estimating the gravity model explaining the importance of the LPI components by geographical region. Finally, section VII summarizes the main conclusions of the research.

\section{Literature review}

The term 'trade facilitation' has been used frequently in recent studies, although they have not provided a homogenous definition. The World Trade Organization (WTO) defines it as: "the simplification and harmonisation of international trade procedures... in collecting, presenting, communications and processing data required for the movement of goods in international trade". Other organizations go even further by including technical trade barriers, competitiveness policies, governmental procedures and transparency in general. Wilson et al. (2005) define trade facilitation using four indicators: port efficiency, customs, regulations and use of e-commerce, analysing their 
statistical significance with a gravity model for a sample of 75 countries. Soloaga et al. (2006) apply the same definition to analyse the impact of changes in the trade facilitation of Mexican industrial goods flows, suggesting that trade reform could boost total Mexican exports by $22.4 \%$.

Other researchers such as Iwanow and Kirkpatrick (2009) adopt the same definition applied to manufacturers' exports from Africa, also concluding that trade facilitation reform could help to improve trade flows. More recently, Moïsé et al. (2011) constructed 12 indicators for the main WTO political areas of negotiation, to estimate the impact of such interventions on the trade of a given country.

However, other studies have used one specific indicator to estimate trade facilitation and ascertain its impact on exports (UNDP, 2001; OECD, 2003; Dennis, 2006; Decreux and Fontagne, 2006; Behar and Manners, 2008). Using the LPI as an explanatory variable of trade, Korinek and Sourdin (2011) confirm the marked impact that logistics performance has on trade, particularly where improvements in infrastructure are concerned, above all in middle-income countries and more specifically for exporters. Meanwhile, administrative improvements have a greater impact on importing countries. Martí et al. (2014) use the LPI as a proxy for trade facilitation, concluding that the more complex goods are in terms of transport, the greater the influence of logistics. This study follows the same line of research, using the index published by the World Bank to analyse the relationships between bilateral exports and logistics.

The distinctive features of the legislation in each country affect international goods flows to a great extent. Hollweg and Wong (2009) build an index of regulatory restrictions in logistics for the Association of Southeast Asian Nations (ASEAN), finding that the index and LPI are negatively correlated, that is, the countries with less 
legal barriers obtain a better logistics score. The possible restrictions or obstacles that authorities place in the path of trade result in increased time and higher costs, thereby reducing competitiveness.

Some research published recently links the LPI to other aspects of development. In this sense, Guner and Coskun (2012) seek a relationship between development in logistics, measured by the LPI, and other economic and social factors, focusing on the 26 OECD members. Min and Kim (2010) combine the LPI and the environmental development index to construct the hybrid index called the "Green LPI", using Data Envelopment Analysis (DEA) to do so. Higher levels of efficiency in logistics are occasionally achieved at the cost of more emissions of pollutants, but the LPI does not take environmental damage into consideration.

Another distortion this index is due to its direct relations to the levels of income. Developed countries such as USA, Germany and Singapore combine high income with a leading position in the index. Similarly, China, India and Vietnam, countries all considered low cost producers, are ranked higher than other developed nations such as Portugal, Greece and Iceland. In this sense, Hoekman and Nicita (2008 and 2010), using the LPI and Doing Business, suggest that tariff and non tariff barriers are still a significant obstacle for trade in countries with lower levels of income.

On a different note, researchers have also attempted to ascertain the importance of the components of the LPI with regard to trade, either by including several components in the same model (Felipe and Kumar, 2012) or by estimating regressions that consider only one of the components (Hertel and Mirza, 2009; Puertas et al., 2013). Both papers 
conclude that infrastructure is the most important component in comparison to customs efficiency ${ }^{1}$.

However, it is worth highlighting the differences between these last two studies and the one we propose in this paper. In the first place, the articles above focused on analysing the LPI for one year alone. For example, Felipe and Kumar (2012) analysed 2005 and Hertel and Mirza (2009) concentrated on data for 2001. We compare data from 2005 to 2010, which means we can detect whether any significant changes have taken place and therefore can provide enhanced conclusions. Secondly, the papers mentioned previously refer to one sole geographical area, while this study aims to identify the possible differences between the five groups of emerging countries considered. Finally, this study analyses a greater number of exporters and importers.

\section{Description and analysis of the Logistics Performance Index}

Trade and logistics involve a number of policies for are critical to a country's business competitiveness. Until 2005, those responsible did not have sufficient information available to them to make comparisons and identify barriers to trade, and thus the LPI is a key instrument that explains the relationship between trade and transport facilitations. It has helped increase awareness of the issue, establishes priorities for reform and strengthen public-private dialogue, and promotes trade and transport in different countries (Banco Interamericano de Desarrollo, 2010.)

The World Bank has published this index for three years (Arvis et al., 2007, 2010 and 2012), ranking 150 countries $^{2}$ and providing an extensive explanation of logistic performance of these countries. The first edition depicts data compiled in 2005 and

\footnotetext{
${ }^{1}$ Virjil and Wagner (2012) reach the same conclusion, building another index.

${ }^{2}$ The LPI published in 2010 and 2012 include 155 countries. However, to carry out the comparison between countries in the empirical section of the study, only the countries that were included in both the LPI published in 2007 and 2012 were used.
} 
published in 2007, the second contains data processed between 2008 and 2009 and published in 2010 and the latest edition refers to information for 2010 that was published in 2012. The index makes an important statistical contribution by establishing a harmonized scale of all the countries in order to identify the difficulties faced by bilateral trade, together with their requirements in terms of logistics associated from the existing facilities. It is a robust combination of several dimensions from an international perspective and is constructed using standard econometric techniques to maximize significance and improve confidence levels.

The LPI is built on the basis of a worldwide survey carried out on companies responsible for the transport of goods and for the facilitation of trade globally. Specifically, it was developed with the assistance of over 800 professionals involved across the different areas of the sector's lines of activity ${ }^{3}$. Each respondent to the survey was asked for data pertaining to the eight countries they most traded with at international level, and over 5,000 assessments were obtained for each country.

The aggregate index is calculated by analysing six main components, being the indicators the following: customs, infrastructure, international shipments, competence, tracking and timeliness. ${ }^{4}$. None of these independently guarantee a good level of logistics performance, and their inclusion is conditioned to empirical studies and extensive interviews carried out with specialists on international freight transport. Each component is defined as follows:

- Customs: measures the efficiency and effectiveness of the customs despatch procedure (speed, simplicity and predictability of customs agencies). All of this is configured through a series of administrative tasks that allow the existing

\footnotetext{
${ }^{3}$ The questionnaire is available at www.worldbank.org/lpi

${ }^{4}$ The LPI published in 2010 and 2012 only take six indicators into consideration (they exclude the domestic logistics costs included in 2007.)
} 
legislation on international trade to be implemented and taxes on the import/export of goods and services to be collected.

- Infrastructure: measures the quality of the country's transport and telecommunications infrastructure. It is related to the procedure used for moving the goods to the final consumer, and is not totally controlled by companies due to external factors. However, it is important to measure how organizations cope with the available facilities, being either an advantage or an obstacle that prevents them from being competitive.

- International shipments: measures how easy it is to arrange shipments at competitive prices.

- Logistics quality and competence: measures the competence and quality of logistics services. It shows how certain parties within the organizational structure behave, representing the quality of service to the customer and optimizing the relationship between organizations and consumers.

- Tracking and tracing: measures the tracking and tracing of shipments. It is important to identify the exact location and the route of each consignment up to its delivery to the end customer. All parties in the good's supply chain are involved in this component, and consequently traceability is the result of the activity of the sector as a whole.

- Timeliness: measures the punctuality of shipment delivery times. This is an important factor for consideration, because with the existing high level of competition, failure to comply with delivery schedules is unacceptable. This has influenced the need for increasingly sophisticated computerization processes. 
These components cover the various areas that define LPI and it has been proved that they have a greater impact than distance and transport costs (Korinek and Sourdin, 2011). Specifically, they include elements of essential logistical value, such as the transparency of processes and their quality, as well as the predictability and reliability of services.

The indicators have been added and properly weighted, receiving a score of 1 to 5 where the higher value represents better logistics. In practice, the LPI usually sits between the maximum of 4.2 in Singapore to the low of 1.2 corresponding to Afghanistan in 2005. The countries that occupy the top positions have large distribution platforms and industries specialised in logistics services, which tend to benefit from economies of scale, and are the source of major technological innovations. The other end of the spectrum is occupied by countries characterized by low income that are landlocked or geographically isolated, or are affected by conflict. However, it should be noted that revenue is not a decisive factor, as, in developing countries where trade has been critical for accelerating growth, logistics is significantly more developed than in other countries with similar incomes.

Arvis et al. (2007) reach the conclusion that the countries with the most predictable, efficient and best managed transport routes and trade procedures are, moreover, those which are most likely to make the most of technological advantages, economic liberalisation and access to international markets. Therefore, the ranking established by the index places the developed nations at the top, while emerging nations occupy completely mixed positions. For example, China was ranked ahead of the oil producing nations in 2005 , due to the fact that some of the petroleum exporters tend to underestimate their logistics. This is the case with Algeria (140th), which is ranked well below neighbouring countries such as Tunisia (60th) and Morocco (94th). In these 
countries, this is due to the absence of incentives and pressure from the private sector to implement institutional reform in favour of trade and transport. However, in some emerging economies where manufacturing accounts for a greater share of exports, the private sector has proposed significant logistics reforms.

In the LPI data for 2008, in comparison to 2005, the top positions of the ranking are held by developed nations (Germany, Switzerland and the Netherlands). However, a general decrease in scores is observed and can be explained by the restrictive measures taken by some countries during the global financial crisis. Seven out of the top 10 ranked countries in the 2005 index averaged scores of more than four points, whereas in 2008 only four countries achieved that average. In reference to the 10 lowest ranked countries, the 2008 index registers changes with regard to 2005, with medium to low income countries from Africa occupying those positions. The case of Sudan is particularly surprising, falling down the ranking from 64th in 2005 to 146th in 2008, cases like this one representing a behaviour difficult to explain in economic terms.

The results of both the 2005 and the 2008 LPI clearly show that there is a logistics gap between developed and emerging nations that is difficult to overcome. Nevertheless, worth highlighting is the improvement recorded by some countries in aspects related to the modernization of customs, the use of information technologies and growth in private logistics services, which has allowed these countries to climb up the ranking. For example, Colombia improved from 82nd to 72nd and Brazil from 61st to $41^{\text {st }}$, due to the effort that Latin America is doing to growth his external sector.

The LPI data for 2010 indicates that the difference between the score assigned to the top-ranked country (Singapore with 4.13) and the bottom-ranked country (Burundi with 1.61) is the same as that recorded in 2008, evidencing methodological consistency. This shows that gap between developed nations and the poorest countries has not 
narrowed, partly due to the economic recession suffered by some regions and which has spread to other trading partners. However, it is worth highlighting the advance that certain countries have made in the ranking over these two years. This is the case of China, which, on the back of an accelerated economic growth, has also improved its trade facilitation, rising from 13th in the 2008 index to second in 2010. Another similar case is Finland, which rose from 12th to 3rd.

Figure 1. Evolution of LPI by geographical area in 2005 and 2010 (range of 1-5, being 1 the lowest)

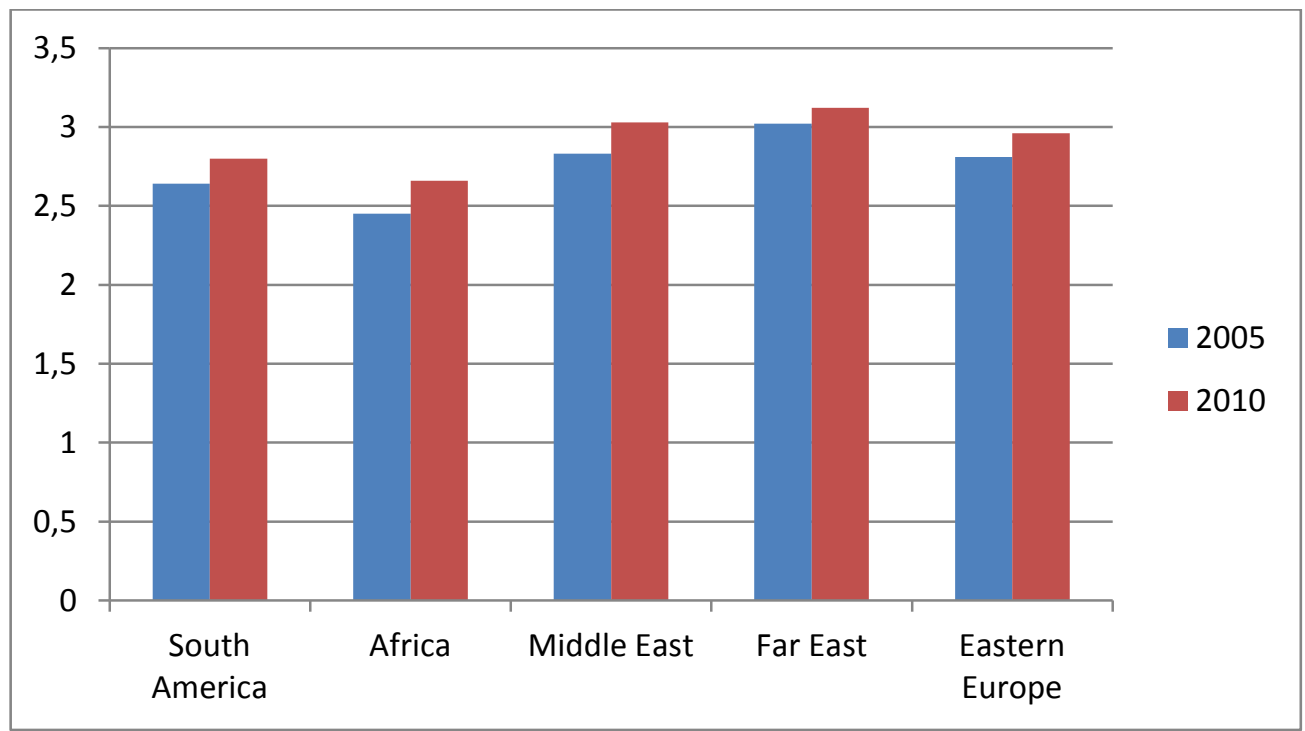

Source: Compiled from World Bank data. Arvis et al. (2007 and 2012)

As can be observed in Fig. 1, the Far East shows the highest LPI scores of the regions under analysis. This region includes countries such as Malaysia and China, with LPI scores of 3.49 and 3.52, respectively in 2010. However, when we consider the change in the LPI over the five years studied, Africa, despite recording lower scores, is the top-ranked country in terms of improvement, rising from an average LPI of 2.45 to 2.66, up by $8.57 \%$. Egypt figures prominently in this regional gain, with a $26 \%$ increase. Although the Far East recorded the smallest increase (3.31\%), the region's 
prominent position in the ranking explains the diminishing evolution in percentage terms.

Nevertheless, this index suggests that still exist the need for policies aimed the better off logistics services combined with an integrated system comprising improvements in infrastructure and public and private services. Reforms should not only focus on reducing costs and time, but could also make advances in the predictability and reliability of deliveries, which are difficult issues to measure with quantitative parameters.

\section{Methodology}

Tinbergen (1962) and Pöyhönen (1963a, b) are generally considered to have pioneered the use of gravity models in international trade, conducting separate research, by coinciding practically in time. Since then, this approach has been used frequently to analyse international trade. Bergstrand $(1985,1989)$ found theoretical grounds for bilateral trade in a series of studies that linked gravity equations to monopolistic competition models. Helpman and Krugman (1985) justified the gravity model by introducing non uniform goods with increasing returns to scale. Meanwhile, Otsuki et al. (2000) used a gravity equation to explain country trade patterns. Anderson and Wincoop (2003) develop a method that consistently and efficiently estimates a theoretical gravity equation and correctly calculates the comparative statics of trade frictions. Martinez-Zarzoso and Suarez-Burguet (2000) presented a theoretical model in which supply side differences among countries determine international trade flows.

Recent research has incorporated variables representing improvements in logistics into these models (Hausman et al., 2005; Prabir, 2007; Iwanow and Kirkpatrick, 2009; Portugal-Perez and Wilson, 2010). They highlight the usefulness of this methodology in 
the study to be undertaken. The basic idea behind a gravity equation is that bilateral trade is explained by:

- Factors related to the potential of a country to export goods and services

- Factors that explain how prone a country is to import goods and services

- Other forces that attract bilateral trade

In its simplest form, a gravity model considers that bilateral trade flows depend positively on the volume of income in both economies and negatively on the distance between them, in line with Newtonian gravitational attraction. Empirical research often includes dummy variables to capture the effects of some factors that can favour trade, such as a colonial link, a common language, sharing a common border, etc. The gravity model used in this study for each area analysed is structured as follows:

$$
\begin{aligned}
& \log \left(X_{i j}\right)=\beta_{0}+\beta_{1} \log \left(D_{i}\right)+\beta_{2} \log \left(Y_{i}\right)+\beta_{3} \log \left(Y_{j}\right)+\beta_{4} \log \left(P_{i}\right)+ \\
& +\beta_{5} \log \left(P_{j}\right)+\beta_{6} \log \left(\operatorname{LPI}_{i}\right)+\beta_{7} \log \left(\operatorname{LPI}_{j}\right)+\beta_{A} W+u_{i j}
\end{aligned}
$$

where:

$$
\begin{aligned}
& X_{i j}: \text { Quantity exported by country } i \text { to country } j \\
& D_{i j}: \text { Distancia bewteen country } i \text { and country } j \\
& Y_{i}: \text { GDP of country } i \\
& Y_{j}: \text { GDP of country } j \\
& P_{i}: \text { Population of country } i \\
& P_{j}: \text { Population of country } j \\
& \operatorname{LPI}_{i}: \text { Logistics Performance Index for country } i \\
& \operatorname{LPI}_{j}: \text { Logistics Performance Index for country } j
\end{aligned}
$$
colonisers)

W: Dummy variables (Border, official languages, second languages and

According to equation (1), exports depend on economic, geographic and demographic variables together with logistics variables. This approach is based on the hypothesis that the variables included in the model have a significant impact on trade 
and signs are coherent with economic theory. The distance variable is an approximate indication of trading costs, which is not without its problems, as it assumes that transport costs are independent of the medium used and that capital cities are a good approximation of the economic centres of a country. The effect of distance between countries $\left(\beta_{1}\right)$ should be negative, because proximity promotes a growth in trade.

Theoretically, the GDP coefficients of both the exporter and also the importer ( $\beta_{2}$ and $\beta_{3}$ ) will be positive, as the larger the economy is, the more exports and imports can be expected. Furthermore, the population coefficient for the exporting country $\left(\beta_{4}\right)$ could be either positive or negative, depending on whether the most populated country exports less due to absorbing domestic production, or exports more due to the predominating technological and logistics variables associated with the level of economic development. At the same time, the coefficient of the importer population $\left(\beta_{5}\right)$ also has an ambiguous sign, for the same reasons as those stated above.

In accordance with the objective of this research, we include the exporter and importer LPI in the gravity model. Both variables have coefficients $\left(\beta_{6}\right.$ and $\left.\beta_{7}\right)$ that represent the importance of trade facilitation in export flows. Consequently, a positive sign is expected in both cases. Finally, a series of dummy variables represent the existing social and cultural similarities between countries in the geographical regions analysed.

The study also focuses on analysing the importance of each LPI component in trade flows. The fact that the components of the LPI are markedly correlated means it is not feasible to estimate one single equation including all the components, as doing so would lead to multicollinearity and erroneous results. Therefore, regressions similar to 
equation (1) have been estimated, including each index component separately. As a result, the following equations have been formulated:

$\log \left(X_{i j}\right)=\beta_{0}+\beta_{1} \log \left(D_{i}\right)+\beta_{2} \log \left(Y_{i}\right)+\beta_{3} \log \left(Y_{j}\right)+\beta_{4} \log \left(P_{i}\right)+$

$+\beta_{5} \log \left(\mathrm{P}_{\mathrm{j}}\right)+\beta_{6} \log \left(\mathrm{Customs}_{\mathrm{i}}\right)+\beta_{7} \log \left(\right.$ Customs $\left._{\mathrm{j}}\right)+\beta_{\mathrm{A}} \mathrm{W}+\mathrm{u}_{\mathrm{ij}}$

$\log \left(X_{i j}\right)=\beta_{0}+\beta_{1} \log \left(D_{i}\right)+\beta_{2} \log \left(Y_{i}\right)+\beta_{3} \log \left(Y_{j}\right)+\beta_{4} \log \left(P_{i}\right)+$

$+\beta_{5} \log \left(\mathrm{P}_{\mathrm{j}}\right)+\beta_{6} \log \left(\right.$ Instrastructure $\left._{\mathrm{i}}\right)+\beta_{7} \log \left(\right.$ Instrastructure $\left._{\mathrm{j}}\right)+\beta_{\mathrm{A}} \mathrm{W}+\mathrm{u}_{\mathrm{ij}}$

$\log \left(X_{i j}\right)=\beta_{0}+\beta_{1} \log \left(D_{i}\right)+\beta_{2} \log \left(Y_{i}\right)+\beta_{3} \log \left(Y_{j}\right)+\beta_{4} \log \left(P_{i}\right)+$

$+\beta_{5} \log \left(\mathrm{P}_{\mathrm{j}}\right)+\beta_{6} \log \left(\right.$ International Shipments $\left.\mathrm{s}_{\mathrm{i}}\right)+\beta_{7} \log$ (International Shipments $\left.\mathrm{j}_{\mathrm{j}}\right)+\beta_{\mathrm{A}} \mathrm{W}+\mathrm{u}_{\mathrm{ij}}$

$\log \left(X_{i j}\right)=\beta_{0}+\beta_{1} \log \left(D_{i}\right)+\beta_{2} \log \left(Y_{i}\right)+\beta_{3} \log \left(Y_{j}\right)+\beta_{4} \log \left(P_{i}\right)+$

$+\beta_{5} \log \left(\mathrm{P}_{\mathrm{j}}\right)+\beta_{6} \log \left(\right.$ Competence $\left._{\mathrm{i}}\right)+\beta_{7} \log \left(\right.$ Competence $\left._{\mathrm{j}}\right)+\beta_{\mathrm{A}} \mathrm{W}+\mathrm{u}_{\mathrm{ij}}$

$\log \left(X_{i j}\right)=\beta_{0}+\beta_{1} \log \left(D_{i}\right)+\beta_{2} \log \left(Y_{i}\right)+\beta_{3} \log \left(Y_{j}\right)+\beta_{4} \log \left(P_{i}\right)+$

$+\beta_{5} \log \left(\mathrm{P}_{\mathrm{j}}\right)+\beta_{6} \log \left(\right.$ Tracking $\left._{\mathrm{i}}\right)+\beta_{7} \log \left(\right.$ Tracking $\left._{\mathrm{j}}\right)+\beta_{\mathrm{A}} \mathrm{W}+\mathrm{u}_{\mathrm{ij}}$

$\log \left(\mathrm{X}_{\mathrm{ij}}\right)=\beta_{0}+\beta_{1} \log \left(\mathrm{D}_{\mathrm{i}}\right)+\beta_{2} \log \left(\mathrm{Y}_{\mathrm{i}}\right)+\beta_{3} \log \left(\mathrm{Y}_{\mathrm{j}}\right)+\beta_{4} \log \left(\mathrm{P}_{\mathrm{i}}\right)+$

$+\beta_{5} \log \left(\mathrm{P}_{\mathrm{j}}\right)+\beta_{6} \log \left(\right.$ Timeliness $\left._{\mathrm{i}}\right)+\beta_{7} \log \left(\right.$ Timeliness $\left._{\mathrm{j}}\right)+\beta_{\mathrm{A}} \mathrm{W}+\mathrm{u}_{\mathrm{ij}}$

It was initially expected that each component displays a significant and positive coefficient, such that higher values of these variables favour international trade. Comparing the results of the estimation allows the component that has the greatest impact on trade flows to be ascertained, as well as to identify changes undergone over the period (2005 and 2010). 
A key issue estimating gravity models is how to deal with zero bilateral trade. Theoretically, zero trade might not be missing information and zero-trade may actually be reflecting the absence of any trade between country pairs. Frequently, the zeros are not randomly distributed, which leads to the problem of selection bias if zero trade observations were to be dropped. Recent literature illustrates that a sample selection bias can arise if the gravity model is estimated by OLS. To deal with this problem, Heckman (1979) proposed the use of Heckman two-step procedure. This procedure entails first estimating a probit model that determines the probability that a country pair engages in trade. Next, a gravity regression with a selectivity variable obtained from the probit regression is performed. In our estimates we use the Heckman model to avoid this sample selection bias.

\section{Variables and sample}

The gravity model used in this study has been estimated for countries grouped in five emerging geographical regions and which have a maritime boundary, namely:

- South America: Argentina, Brazil, Chile, Colombia, Costa Rica, Ecuador, El Salvador, Guatemala, Guyana, Honduras, Jamaica, Mexico, Panama, Peru, Uruguay and Venezuela.

- Africa: Algeria, Benin, Cameroon, Egypt, Gabon, Gambia, Ghana, Kenya, Madagascar, Mauritius, Morocco, Mauritania, Namibia, Senegal, South Africa, Sudan, Togo and Tunisia.

- Middle East: Saudi Arabia, Cyprus, UAE, Iran, Jordan, Oman, Pakistan, Qatar, Syria, Turkey and Yemen.

- Far East: China, India, Indonesia, Malaysia, Sri Lanka, Thailand and Vietnam. 
- Eastern Europe ${ }^{5}$ : Russia, Poland, Romania, Bulgaria, Ukraine, Lithuania, Latvia and Estonia.

Furthermore, the importers included in the model are the 140 countries whose LPI for 2005 and 2010 were published by the World Bank. As a result, the research focuses mainly on maritime trade flows where the ultimate goal is to analyse the importance of trade facilitation.

The information on trade flows comes from the UN Comtrade database. As regards the explanatory variables, distance between countries expressed in kilometres was calculated as the straight-line distance between capital cities ${ }^{6,}$ which acts as an estimation in view of the difficulty involved in locating producer regions that are often spread across the entire territory. GDP (in dollars) and population data were obtained from the United Nations database. Finally, the series of dummy variables describing social and cultural features of countries that make up the areas were obtained from Centre d’Etudes Prospectives et d’Informations Internationals (CEPII).

It was found that no multicollinearity exists between the variables using the matrix of correlations and the identification of the Variance Inflation Factor (VIF) ${ }^{7}$ as a basis. Furthermore, use of graphs has enabled the normality of the residuals to be shown, as well as the absence of heteroskedasticity.

\footnotetext{
${ }^{5}$ This group of countries includes some members of the European Union. However, based on their level of logistic development, we think it is methodologically justified.

${ }^{6} \mathrm{http}: / /$ www.cepii.fr/anglaisgraph/bdd/distances.htm

${ }^{7}$ VIF represents the increase in variance due to the presence of collinearity. The VIF are the elements in the diagonal of the $\mathrm{C}^{-1}$ matrix, which is the inverse of the $\mathrm{C}$ correlation matrix. A predictor variable with a VIF greater than 10 (this is equivalent to accepting that a $\mathrm{R}^{2}=.90$ is indicative of a good linear relationship), can cause multicollinearity.
} 


\section{Results}

A gravity model was initially estimated for each of the geographical regions and all the countries considered, taking the LPI as an indicator of the impact of trade facilitation on export flows in 2005 and 2010 (Table 1). 
Table 1. Gravity model results

\begin{tabular}{|c|c|c|c|c|c|c|c|c|c|c|c|c|}
\hline & \multicolumn{2}{|c|}{ AFRICA } & \multicolumn{2}{|c|}{ EASTERN EUROPE } & \multicolumn{2}{|c|}{ FAR EAST } & \multicolumn{2}{|c|}{ SOUTH AMERICA } & \multicolumn{2}{|c|}{$\begin{array}{c}\text { MIDDLE } \\
\text { EAST }\end{array}$} & \multicolumn{2}{|c|}{ ALL COUNTRIES } \\
\hline & 2005 & 2010 & 2005 & 2010 & 2005 & 2010 & 2005 & 2010 & 2005 & 2010 & 2005 & 2010 \\
\hline Constant & $-10.072 * * *$ & $-9.433 * * *$ & $-4.725 * *$ & $-6.845 * * *$ & $-13.574 * * *$ & $-13.454 * * *$ & $-9.927 * * *$ & $-11.194 * * *$ & $-11.311 * * *$ & $-13.054 * * *$ & $-11.767 * * *$ & $-11.345^{* * *}$ \\
\hline Distance & $-1.254 * * *$ & $-1.855^{* * *}$ & $-1.382 * *$ & $-1.407 * * *$ & -.556 & -.571 & $-1.951 * * *$ & $-1.951 * * *$ & $-1.311 * * *$ & $-1.438 * * *$ & $-1.301 * * *$ & $-1.976 * * *$ \\
\hline GDP Export & $1.118 * * *$ & $.599 * * *$ & .152 & $.396 * * *$ & $.876 * * *$ & .669 & $.853 * * *$ & $.221 *$ & $.701 * * *$ & $1.037 * * *$ & $.927 * * *$ & $.598 * * *$ \\
\hline GDP Import & $.317 * * *$ & $.425 * * *$ & $.622 * * *$ & $.542 * * *$ & $.653 * * *$ & $.652 * * *$ & $.834 * * *$ & $.708 * * *$ & $.451 * * *$ & $.456 * * *$ & $.579 * * *$ & $.529 * * *$ \\
\hline Pop Export & $-.146 * *$ & $.139 *$ & $.816 * * *$ & $.501 * * *$ & -.053 & $0.152)$ & $.272 *$ & $.495 * * *$ & $.362 * * *$ & $.206 * * *$ & $.214 * * *$ & $.387 * * *$ \\
\hline Pop Import & $.526 * * *$ & $.475^{* * *}$ & $.272 * *$ & $.321 * * *$ & $.285 * *$ & .272 & $.173 * * *$ & $.295 * * *$ & $.487 * * *$ & $.520 * * *$ & $.324 * * *$ & $.359 * * *$ \\
\hline LPI Export & $3.519 * * *$ & $10.209 * * *$ & -.482 & $2.207 * * *$ & $6.754 * * *$ & $8.941 *$ & $4.359 * * *$ & $17.398 * * *$ & $5.663 * * *$ & $3.852 * * *$ & $4.740 * * *$ & $11.483 * * *$ \\
\hline LPI Import & $4.371 * * *$ & $4.730 * * *$ & $2.662 * * *$ & $4.161 * * *$ & $3.088 * * *$ & 2.532 & $2.291 * * *$ & $4.299 * * *$ & $2.939 * * *$ & $2.918 * * *$ & $2.940 * * *$ & $4.017 * * *$ \\
\hline Border & $.389 *$ & $.438^{*}$ & .260 & $.288^{*}$ & .718 & .678 & -.040 & -.208 & .226 & .128 & $.296 * * *$ & $.483 * *$ \\
\hline Official language & .317 & .151 & .588 & .231 & -.402 & -.134 & -.041 & .053 & $.843 * * *$ & $.432 * * *$ & $.383 * * *$ & -.055 \\
\hline Second language & -.048 & $.529 * *$ & $.080^{*}$ & .501 & .323 & -.107 & -.165 & .159 & .095 & $.448 * * *$ & -.037 & $.605^{* * *}$ \\
\hline Colony & .132 & .496 & -.212 & -.094 & .340 & .148 & .319 & -.096 & .312 & .092 & .168 & .648 \\
\hline Comcol & $.264 * * *$ & $.319 * * *$ & .709 & $1.077 * * *$ & .179 & .215 & $.947 * *$ & $.999 * * *$ & $.279 * *$ & $.354 * * *$ & $.365 * * *$ & .325 \\
\hline Col45 & .556 & -.166 & .634 & $.984 * *$ & .611 & .281 & .891 & 1.238 & .007 & .211 & $.369 *$ & .291 \\
\hline Smctry & .193 & .258 & -.633 & -.523 & .142 & .352 & .149 & $.142)$ & -.409 & $-1.427 * *$ & .186 & .337 \\
\hline Mills lambda & -.642 & .555 & -2.054 & -.522 & 1.904 & 2.809 & -.699 & -.959 & 1.385 & .822 & -.532 & $2.085^{* *}$ \\
\hline
\end{tabular}


Table 1 shows that the results obtained from the second stage Heckman procedure are non biased estimates. The distance variable is significant in all cases, presenting a negative sign according to the premise that the greater the distance, the lower the trade relations between countries, and also with elasticity close to $1.5 \%$ (in absolute value) a level considered standard in the literature on gravity equations. Meanwhile, income indicators such as the GDP of the exporting and importing countries have significant coefficients with positive signs, implying that the higher a country's level of production, the more it trades.

The variable LPI displays significant and positive coefficients in the case of both the exporter and the importer for the sample containing all the countries (last two columns in the table). However, it is worth highlighting the fact that logistics has more of an impact on exporter trade (4.740 and 11.483) than on importer trade (2.940 and 4.017). This trend is repeated in the analysis by region, due to the different levels of economic development between the two types of countries. Exporters are emerging nations, while importers include both developed and emerging countries. As a result, an improvement in the infrastructure or customs procedures in an emerging country, due to its previous deficiencies has a greater impact on trade than in the case of developed nations.

The influence of the LPI as a proxy of logistics presents variations between 2005 and 2010, justified by the efforts that emerging countries are making to improve logistics in their international trade operations. More specifically, the coefficients for the exporter LPI are much higher in this case. The coefficients of exporters LPI from Eastern Europe and South America were not significant in 2005, but this result changes five years later. Moreover, it is worth highlighting that logistics has gained importance in all regions, particularly in Africa, where 
exporters LPI changed its coefficient from 3.519 to one of 10.209 and in South America the coefficient increased from 4.359 to 17.398 . In contrast, logistics continues to have a similar impact on trade when the LPI of importers is considered.

In keeping with the objective of this research, we have performed estimations for each of its LPI components, as explained in the section on methodology. The coefficients of these components are displayed below (Table 2).

Table 2. LPI components. 2005

\begin{tabular}{|c|c|c|c|c|c|c|c|c|}
\hline & & LPI & Customs & Infrastruc. & $\begin{array}{c}\text { Intern. } \\
\text { Shipments }\end{array}$ & Competence & Tracking & Timeliness \\
\hline \multirow{2}{*}{$\begin{array}{c}\text { All } \\
\text { Countries }\end{array}$} & Export & $4.740 * * *$ & $3.794 * * *$ & $4.301 * * *$ & $3.108 * * *$ & $3.230 * * *$ & $3.479 * * *$ & $3.782 * * *$ \\
\hline & Import & $2.940 * * *$ & $2.491 * * *$ & $2.779 * * *$ & $2.447 * * *$ & $2.251 * * *$ & $2.051 * * *$ & $1.461 * * *$ \\
\hline \multirow[t]{2}{*}{ Africa } & Export & $3.519 * * *$ & $2.901 * * *$ & $3.364 * * *$ & $2.920 * * *$ & $1.704 * * *$ & $1.816^{* * *}$ & $1.330 * *$ \\
\hline & Import & $4.372 * * *$ & $3.762 * * *$ & $4.379 * * *$ & $3.242 * * *$ & $3.375^{* * *}$ & $3.240 * * *$ & $2.225^{* * * *}$ \\
\hline \multirow{2}{*}{$\begin{array}{l}\text { Eastern } \\
\text { Europe }\end{array}$} & Export & -.482 & .574 & 1.032 & -2.842 & -.387 & -.199 & .367 \\
\hline & Import & $2.662 * * *$ & $2.376^{* * *}$ & $2.510 * *$ & $2.933 * * *$ & $1.819 * * *$ & $1.566^{* *}$ & .963 \\
\hline \multirow[t]{2}{*}{ Far East } & Export & $6.754 * * *$ & $4.713 * * *$ & $4.965 * * *$ & $5.408 * * *$ & $7.668 * * *$ & $8.144 * * *$ & 1.240 \\
\hline & Import & $3.088 * * *$ & $2.489 * * *$ & $2.797 * * *$ & $2.415^{* * * *}$ & $2.350 * * *$ & $2.237 * * *$ & $1.738 * *$ \\
\hline \multirow{2}{*}{$\begin{array}{c}\text { South } \\
\text { America }\end{array}$} & Export & $4.359 * * *$ & $2.099 * * *$ & $5.204 * * *$ & .232 & $6.728 * * *$ & $5.852 * * *$ & $2.917 * * *$ \\
\hline & Import & $2.291 * * *$ & $1.851 * * *$ & 1.881 & $2.184 * * *$ & $1.910 * * *$ & $1.584 * * *$ & $1.147 * *$ \\
\hline \multirow{2}{*}{$\begin{array}{c}\text { Middle } \\
\text { East }\end{array}$} & Export & $5.663 * * *$ & $5.278 * * *$ & $4.458 * * *$ & $3.965 * * *$ & $3.382 * * *$ & $4.060 * * *$ & $5.595 * * *$ \\
\hline & Import & & $2.484 * * *$ & $3.025 * * *$ & $2.223 * * *$ & $2.231 * * *$ & $1.917 * * *$ & $1.400 * * *$ \\
\hline
\end{tabular}

The results for 2005 show that not only for the aggregate index, but also for each of the components, the parameter value is higher when logistics facilities are considered from the perspective of the exporter, confirming the comments made earlier. Furthermore, we can identify two different behaviours: on the one hand, Africa and Eastern Europe, whose exports are more affected by the importer's 
logistics, and on the other, the Far East, South America and the Middle East, where the performance of the own indicators have a greater weight in export volumes.

Focusing on the results obtained by exports for the set of countries as a whole, the most important components are infrastructure, timeliness and customs. By geographical area, infrastructure is the most important only in Africa, timeliness only in the Middle East, while customs was not the most important component in any area. As a result, none of the components appear to lead the way in terms of explaining the role of logistics in export flows.

Table 3. LPI components. 2010

\begin{tabular}{|c|c|c|c|c|c|c|c|c|}
\hline & & LPI & Customs & Infrastruc. & $\begin{array}{c}\text { Intern. } \\
\text { Shipments }\end{array}$ & Competence & Tracking & Timeliness \\
\hline \multirow{2}{*}{$\begin{array}{c}\text { All } \\
\text { Countries }\end{array}$} & Export & $11.483 * * *$ & $6.909 * * *$ & $7.501 * * *$ & $11.621 * * *$ & $9.035 * * *$ & $8.793 * * *$ & $8.449 * * *$ \\
\hline & Import & $4.017 * * *$ & $2.498 * * *$ & $3.081 * * *$ & $3.528 * * *$ & $2.929 * * *$ & $3.161 * * *$ & $3.719 * * *$ \\
\hline \multirow{2}{*}{ Africa } & Export & $10.209 * * *$ & $6.672 * * *$ & $6.597 * * *$ & $10.450 * * *$ & $7.423 * * *$ & $6.894 * * *$ & $7.673 * * *$ \\
\hline & Import & $4.730^{* * *}$ & $2.231^{* * *}$ & $3.605 * * *$ & $4.075^{* * *}$ & $3.746^{* * *}$ & $3.160^{* * *}$ & $4.127 * * *$ \\
\hline \multirow{2}{*}{$\begin{array}{l}\text { Eastern } \\
\text { Europe }\end{array}$} & Export & $2.207 * * *$ & $1.049 * *$ & $2.571 * * *$ & $1.883 * * *$ & $2.915 * * *$ & $3.247 * * *$ & $.963 *$ \\
\hline & Import & $4.161 * * *$ & $2.247 * * *$ & $3.129 * * *$ & $3.845 * * *$ & $2.992 * * *$ & $3.547 * * *$ & $3.949 * * *$ \\
\hline \multirow{2}{*}{ Far East } & Export & $8.942 *$ & $8.244 * * *$ & $3.785 * *$ & $14.812 * * *$ & $-11.285 * * *$ & 2.496 & $8.548^{*}$ \\
\hline & Import & 2.532 & $1.616^{*}$ & 1.396 & $2.286^{* *}$ & $1.755^{* * *}$ & $2.117^{*}$ & 1.670 \\
\hline \multirow{2}{*}{$\begin{array}{c}\text { South } \\
\text { America }\end{array}$} & Export & $17.398 * * *$ & $8.496 * * *$ & $11.286 * * *$ & $17.228 * * *$ & $13.008 * * *$ & $11.519 * * *$ & $8.623 * * *$ \\
\hline & Import & $4.299 * * *$ & $2.664 * * *$ & $2.929 * * *$ & $3.970 * * *$ & $2.499 * * *$ & $3.562 * * *$ & $4.094 * * *$ \\
\hline \multirow{2}{*}{$\begin{array}{c}\text { Middle } \\
\text { East }\end{array}$} & Export & $3.852 * * *$ & $5.341 * * *$ & $4.858 * * *$ & $3.803 * * *$ & $2.718 * * *$ & $.974 * *$ & $1.663 * * *$ \\
\hline & Import & $2.918 * * *$ & $2.239 * * *$ & $1.996 * * *$ & $2.575 * * *$ & $2.381 * * *$ & $2.252 * * *$ & $1.729 * * *$ \\
\hline
\end{tabular}

Note: $*$ denote test statistic significance at the $10 \%$ level, **at the $5 \%, * * *$ at the $1 \%$

With regards the estimations performed for 2010 (Table 3), and focusing on the regressions relating to each of the components in the different areas, special mention must be made to the high level of significance of international shipments, the most important component in Africa, the Far East and South America as well as for the sample of countries as a whole. Meanwhile, customs and tracking stand 
out in South America. Nevertheless, as is the case with the results for 2005, the fact that the various components are markedly significant in the different regions reinforces the global discourse regarding the importance of logistics performance. So, international shipments has gained more importance due to competition in the private sector, between freight carriers and shipping agents, in response to stronger export dynamics in the aforementioned regions, providing charters and services at increasingly competitive prices.

On comparing the results for 2010 with the corresponding regressions for 2005, it can be seen that customs and infrastructure lose value in their coefficients against other components, particularly international shipments. This circumstance is interesting as, while customs and infrastructure basically respond to public policy and stimulus, international shipments, competence, tracing and timeliness are due to the intervention of the private sector, which better anticipates and reacts to market fluctuations.

\section{Conclusions}

The complex network of business relationships has placed logistics in a key role to determine international competitiveness between countries. In recent years, in an attempt to provide information on this, researchers have made a concerted effort to find the indicators that best reflect the logistics situation in each country.

Continuing in similar vein, the aim of this study is to provide an empirical analysis of the situation in developing nations with a maritime boundary, grouped into geographical regions. More specifically, the gravity model has been used to determine the importance of logistics in exports for the regions of Africa, South 
America, Middle East, Far East and Eastern Europe. The LPI published by the World Bank was used to measure trade facilitation. The analysis was conducted for 2005 and 2010, as well as for all the individual components that make up the index in order to detect possible advances achieved by the countries and to ascertain in detail which aspects they should concentrate on.

The results of the empirical study show that exporter trade facilitation measures gained importance over the five-year period, their rise being particularly prominent in countries in Africa, South America and Eastern Europe. LPI coefficients and also its components when analysed individually are significant and positive and in some cases record strong growth both in 2005 and in 2010.

On the whole, all emerging nations have made a big effort to improve their logistics performance in order to improve their trade relations. More specifically, it is worth highlighting the importance that international shipments have acquired, which refers the need to improve the organization of shipments at competitive prices. These countries require significant advances to be able to enter the complex international trade network.

After performing the analysis by geographical region, we also detected the importance that logistics performance is acquiring in their relations. While no single component figures prominently ahead of the rest for all the regions, it can be confirmed that the countries in South America have achieved considerable improvements in facilitating the exportation of their goods. 


\section{References}

Anderson, J.E. and Wincoop, E.van. (2003) Gravity with gravitas: a solution to the border puzzle, The American Economic Review, 93, 170-192.

Arvis, J.F., Mustra, M., Panzer, J., Ojala, L. and Naula, T.( 2007) Connecting to Compete: Trade logistics in the global economy World Bank: Washington.

Arvis, J.F., Mustra, M., Ojala L., Shepherd, B. and Saslavsky D. (2010) Connecting to Compete: Trade logistics in the global economy World Bank: Washington.

Arvis, J.F., Mustra, M., Ojala L., Shepherd, B. and Saslavsky D. (2012) Connecting to Compete: Trade logistics in the global economy World Bank: Washington.

Banco Interamericano de Desarrollo. (2010) Evaluación de la Facilitación del Comercio y el Transporte Banco Mundial: Washington, DC

Behar, A. and Manners, P. (2008) Logistics and exports, African Economics Working Paper Series 293. CSAE WPS/2008-13. Oxford: University of Oxford.

Bergstrand, J.H. (1985) The gravity equation in international trade: some microeconomic foundations and empirical evidence, The Review of Economics and Statistics, 71, 143-153.

Bergstrand, J.H.(1989) The generalized gravity equation, monopolistic competition, and the factorproportions theory in international trade, The Review of Economics and Statistics, 67, 474481.

De Souza, R., Goh, M., Gupta, S. and Lei, L. (2007) An Investigation into the Measures Affecting the Integration of ASEAN's Priority Sectors: Phase 2: The Case of Logistics. REPSF Project No. 06/001d.

Decreux, I. and Fontagne, L. (2006) A quantitative assessment of the outcome of the Doha development agenda. CEPII working paper 2006-10.

Dennis, A. (2006) The impact of regional trade agreements and trade facilitation in the Middle East and North Africa region. World Bank Policy Research Working Paper 3837.

Felipe, J. and Kumar, U. (2012) The Role of Trade Facilitation in Central Asia: A Gravity Model, Eastern European Economics, 50, 5-20.

Guner, S. and Coskun, E. (2012) Comparison of Impacts of Economic and Social Factors on Countries', Logistics Performances: A Study with 26 OECD Countries, Research in Logistics \& Production, 2, 329-343.

Hausman, W., Lee, H.L. and Subramanian, U. (2005) Global logistic indicators, supply chain metrics, and bilateral trade patterns. World Bank Policy Research Working Paper 3773, Washington D.C.

Heckman, J. (1979) Sample selection bias as a specification error, Econometrica, 47, 153-161

Helpman, E and Krugman, P. (1985) Market structure and foreign trade. Increasing returns, imperfect competition and the international economy. The MIT Press, Cambridge, MA/London.

Hertel, T. and Mirza, T. (2009) The Role of Trade Facilitation in South Asian Economic Integration. Study on Intraregional Trade and Investment in South Asia, (ADB, Mandaluyong City).

Hoekman, B. and Nicita, A. (2008) Trade Policy, Trade Costs and Developing Country Trade. World Bank Policy Research Working Paper No. 4797

Hoekman, B. and Nicita A. (2010) Assessing the Doha Round: Market access, transactions costs and aid for trade facilitation, The Journal of International Trade \& Economic Development, 19, 65-79. 
Hollweg, C. and Wong, M. (2009) Measuring Regulatory Restrictions in Logistics Services. ERIA Discussion Paper Series.

Iwanow, T. and Kirkpatrick C. (2009) Trade Facilitation and Manufactured Exports: Is Africa Different?, Word Development, 37, 1039-1050.

Korinek, J. and Sourdin, P. (2011) To what extent are high-quality logistics services trade facilitating?, OECD Trade Policy Working Papers 108. OECD Publishing.

Martí, ML., Puertas, R. and García, L. (2014) Relevance of Trade facilitation in Emerging Countries Export, The Journal of International Trade and Economic Development, 23, 202222.

Martinez-Zarzoso, I. and Suarez Burguet, C. (2000) The determinants of trade performance: influence of R\&D on export flows, Applied Economics, 32, 1939-1946.

Min, H. and Kim. I. (2010) Measuring the Effectiveness of the Conuntry's Green Supply Chain form a Macro Perspective. Proceedings of the First Annual State International Symposium on Green Supply Chains, Canton, Ohio July.

Moïsé, E., Orliac, T. and Minor, P. (2011) Trade facilitation indicators: the impact on trade costs. OECD Trade Policy Working Papers 118, OECD Publishing.

Mustra, M.A. (2011) Logistic Performance Index, Connecting to Compete 2010. UNESCAP Regional Forum and Chief Executives Meeting.

OECD (2003) Quantitative Assessment of the Benefits of Trade Facilitation. TD/TC/WP31,OECD, Paris.

OECD (2005) The Economic Impact of Trade Facilitation. OECD Trade Policy Working Paper No. 21. Paris: OECD.

Otsuki, T., Wilson, J.S. and Sewadeh, M. (2000) Saving two in a Billion: a case Study to Quantify the trade effect of European food safety standards in African exports. World Bank, Washington D.C.

Portugal-Perez, A. and Wilson, J.S. (2010) Export Performance and Trade Facilitation Reform, Policy Research Working Paper 5261 April.

Pöyhönen, P. (1963a) A tentative model for the volume of trade between countries, Weltwirschaftliches Archiv, 16, 93-99.

Pöyhönen, P. (1963b) Toward a general theory of international trade, Ekonomiska Samfundets Tidskrift, 16, 69-78.

Prabir, D. (2007) Impact of trade costs and trade: empirical evidence from Asian countries. AsiaPacific Research and Training Network on Trade Working Paper Series 27 January.

Puertas, R., Marti, L. and García, L. (2013) Logistics performance and export competitiveness: European experience, Empirica Journal of European Economics, on line, DOI $10.1007 / \mathrm{s} 10663-013-9241-\mathrm{z}$

Soloaga, I., Wilson, J.S. and Mejía, A. (2006) Trade facilitation reform and Mexican competitiveness. World Bank Policy Research Working Paper 3953, June.

Tinbergen, J. (1962) Shaping the world Economy: suggestions for international economic policy. New York: The Twentieth Century, Inc.

UNDP (2001) Human Development Report. New York Oxford University Press.

Virjil, M. and Wagner. L. (2012) Does Aid for Trade Enhance Export Performance? Investigating the Infrastructure Channel, The World Economy, 35, 838-868.

Wilson, J.S., Mann C. and Otsuki, T. (2005) Assessing the Benefits of Trade Facilitation: A Global Perspective, The Word Economy, 28, 841-871. 
